INTERNATIONAL JOURNAL OF MULTIDisciplinARY RESEARCH AND ANALYSis

ISSN(print): 2643-9840, ISSN(online): 2643-9875

Volume 05 Issue 02 February 2022

DOI: 10.47191/ijmra/v5-i2-35, Impact Factor: 6.072

Page No. $478-481$

\title{
The Contribution of Alexander Arkadievich Feinberg's Work to Literature
}

\section{Oygul Nematova}

Student, Faculty of first English, Uzbekistan State World Languages University

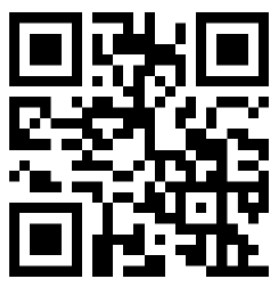

ABSTRACT: Alexander came from a brunette family and was a blue-eyed, gorgeous young man. The well-known poet begins to show his potential at a young age. He was enrolled in the journalism department of Tashkent University's Faculty of Correspondence Philology. He's also the author of works that have been published in Tashkent, Moscow, and St. Petersburg. Alexander Feinberg is unquestionably one of the most prominent figures in Uzbek poetry. His name and work are totally irreplaceable among Uzbek fans and poets. In Feinberg's poetry, the historical and present eras, the West and the East, nationalism and internationalism, and the West and the East were all united to create a separate aesthetic domain. Feinberg's lyrical protagonist is a kind character who has maintained his human traits in the face of historical and societal calamities, who is always prepared to lend a helping hand and who suffers from the world's bad conditions. Feinberg's poetry is a synthesis of significant aesthetic achievements by Russian and European poets. His creative approach is influenced by the traditions of traditional Eastern poetry. Feinberg's method is characterized by artistic translation as well. Alexander has also written the scripts for almost fifty documentaries and seven feature films. Based on a script by Alexander Feinberg, four feature films and over twenty animated features have been produced.

KEY WORDS: Alexander Feinberg, poet, poems, books, epic, collection of poems, protagonist, films, animated films, script, literature, rhythm, writes, journalism, award, produce.

\section{INTRODUCTION}

The Feinberg family's story begins as follows: his father was born in Gatchina, near Sankt-Petersburg, in 1891, while his mother was born in Moscow in 1904. His parents had not escaped the atrocities of what was referred to as "mass repression". Indeed, the author's parents met as a result of the Siberian exile, which drew a substantial number of people during Stalin's leadership. When the scent of Kolima reached Novosibirsk, the poet's parents recognized that the Feinberg surname was not right for surviving the German troops during the Second World War. Two pieces of paper were put in the poet's three-year-old brother's hat. The first writes "Chisinau," whereas the second has "Tashkent." The Feinberg family's eldest son picked "Tashkent," which rescued the whole Feinberg family. Consequently, they arrived in Tashkent in 1937 and two years later, on November 2, 1939. The Russian and Uzbek people's poet Alexander Arkadievich Feinberg was born in Tashkent.

Alexander was a smart, blue-eyed, and handsome boy from a brunette family. His childhood was spent on the former Zhukovsky Street. Alexander Feinberg studied at Tashkent Topographic College after graduating from a seven-year school. After graduating from technical college, he served in the military in Tajikistan to protect his masculinity in his homeland.

Afterwards, he was accepted into Tashkent University's (now the State National University of Uzbekistan) Faculty of Correspondence Philology's journalism department, where he worked for the university newspaper. In 1961, he met Inna Glebovna Koval, his future wife, a talented journalist with a high level of education and intelligence. She always becomes the poet Alexander Feinberg's first reader and an honest critic. We can still see proof that the poet chose a trustworthy partnership since Inna Glebovna remains to effectively communicate the poet's work to fans today.

Alexander graduated from Tashkent State University in 1965 with a degree in journalism. His work is extremely variegated. He has also written books that have been published in Tashkent, Moscow, and Sankt-Petersburg. Artistic translation is yet another prominent feature of Feinberg's approach. Alexander has also scripted approximately fifty documentaries and seven feature films. Four feature films and more than twenty animated features have been created based on a script by Alexander Feinberg. 


\section{The Contribution of Alexander Arkadievich Feinberg's Work to Literature}

Alexander Arkadyevich Feinberg died on October 14, 2009 at his home in Tashkent. He was buried in the communist part of Botkin Cemetery in Tashkent.

\section{MAIN PART}

"Literature indicates not just the heart of the people, but also their spirituality. In today's complex world, it is necessary to find a way into the hearts of people and use the influential power of literature to inspire them to noble goals. We will create all the conditions for studying the heritage of our ancestors and creating great literature worthy of our great culture" Shavkat Mirziyoyev noted. Because of the President's concentration on literature, it prompted me to write about an author who contributed to the literature of the Russian and Uzbek peoples.

At a school age, the well-known poet begins to demonstrate his potential. When Alexander Feinberg's reading of Pushkin's works surprised and captivated everyone, the poet's peers were conducting a monotonous conversation about the poems. Alexander's voice was alive and distinctive, and whenever he said something, he immediately assumed the position, bringing the images and occurrences to reality, just like in a movie. Even before that, he could sense the significance of each word and the poem's rhythm. Feinberg exemplified the friendly linkages that existed between the Uzbek and Russian peoples.

Alexander Feinberg is undoubtedly one of Uzbek poetry's brightest stars. Among Uzbek fans and poets, his name and work are absolutely irreplaceable. His poems have appeared in publications such as "Change", "Youth" ("Yunost"), "New World" ("Noviy mir"), "Eastern Star" ("Zvezda Vostoka"), and "New Volga" ("Novaya Volga"), as well as internationally published in periodicals magazines of the United States, Canada, and Israel. He was engaged by the Writers' Union of Uzbekistan after the publication of his first poetry collection ("Etude"). He served as a consultant for the Uzbek Writers' Union from 1965 to 1969. Etude (1967), Second (1969), Poems (1977), Far Bridges (1978), "Answer" (1982), Short Wave (1983), Spreading net (1984), and Free Sonnets (1990) are among his fifteen published collections of poetry in Tashkent, Moscow, and St. Petersburg. Giving in to a very contemporary literature was really quite acceptable in Soviet times. Feinberg was on a list of famous poets at the time, including Andrei Voznesensky and Rimma Kazakova. In Feinberg's poetry, the historical and contemporary periods, the West and the East, nationalism and internationalism were combined to create a distinct aesthetic realm. Feinberg's lyrical protagonist is a compassionate individual who has been able to fully preserve his human qualities in the moments of historical and social catastrophes, who is always willing to offer a helping hand and who suffers from the world's unpleasant circumstances. Feinberg's poetry is a confluence of Russian and European poets' outstanding artistic accomplishments. The traditions of classical Eastern poetry are no stranger to his creative style.

One of the poems written by the poet to change him and others is the sonnet "Language". As you read this sonnet, the lyrical protagonist, who is silently watching the events of human life without any resistance, comes to life. In this regard, I remembered the following words of the first President, Islam Karimov: "One should be afraid of a person who is neutral and indifferent to what is happening around him or her."

Feinberg's poetry has a lighthearted tone that is humor. He characterized the unchangeable palov of the Uzbek teahouse with such a laugh in the epic "Ruboiy tori," so it's no surprise that it can't be read without a bright smile. You turn back to reading his material, and you're astonished to find out how little you know about him... As you turn the pages of the book, you may glimpse the abyss, the undefined voices of poetry...

There are only a few photographs of Alexander Arkadievich, predominantly from public appearances on the Internet. Of course, we can't ignore the fact that his appearance has been affected by his age. You can see the deep wrinkles on his face... But it's just a photo. I can assure you that he will not create the impression of being an elderly man. His personality is that of a juvenile. In this country, he became a poet and rediscovered his homeland. For him, the theme of the Uzbek community was fundamental, and he worked on it all throughout his life.

Alexander Feinberg, a remarkable translator, has introduced Russian-speaking readers to several masterpieces by well-known Uzbek poets. Alexander's work features a variety of creative translations. Alisher Navoi's epics and poems, as well as other current Uzbek poets' works, have been translated into Russian by the poet, who is well-versed in Uzbek poetry. In Moscow, Erkin Vahidov's epic "Rebellion of Spirits" was published. "Wedge Swans," a collection of poems by Abdulla Aripov, Khosiyat Rustamova, Sirojiddin Said, and Omon Matchon, was published in Tashkent. It is noteworthy that Alexander Feinberg's poems were translated into Uzbek and published under the name "Chigir."

The poet's publication opportunity was shut down for seven years on one day owing to his non-standard behaviour, and this circumstance inspired him to generate film scripts. A total of four feature films and twenty animated features have been produced. He has made seven feature films at the Uzbek film studio: "My Brother," "Under the Hot Sun," "Healed in Kandahar," and "Criminals and Justified" at the Tajik film studio. 


\section{The Contribution of Alexander Arkadievich Feinberg's Work to Literature}

The film "Stadium in the Sky," based on his storyline, was produced in 1999 on the 20th anniversary of the tragic death of the Pakhtakor football team in an aircraft accident. The lyrics for the film were written by Alexander Feinberg in 1979.

In addition to this, A. A. Feinberg also managed the seminar of young Uzbek authors in Tashkent for several years. He is particularly friendly to creative youngsters, and his efforts have supplied encouragement to many early authors.

Murod Muhammad Dost, a writer and scriptwriter, and Jahongir Kasimov, a cinematographer, say about Alexander Feinberg's filmography: "It is imperative to strive to be a controller of artistic reality. He used to be like that, but today just a few people are like that."

"The Giant and the Short was my first full-length film, we have appreciated working on this project because the topic's applicability, eternity, and profundity have greatly contributed to an uninhibited great sense of humor. It also provides a tremendous source of inspiration for its creators. "And all this will pass away," the master said, almost like Solomon. When instructing his colleagues, followers, and students, the poet did not demand knowledge, literacy, philology, or other trickery" Kasimov said.

Our country appreciates the poet, and the author's poetry nights were constantly filled with people. The poet's work is extensive and multifaceted. His poetry is vivacious, with such a wide range of topics, philosophy, complexity, and is found to be predictive. The poet is moved by the phrase, and the readers are captivated by it as well. In Uzbekistan, he lived and worked. The poet values the air, the sky, the soil, the people, in short, the whole being of this nation as precious as a poem, as beloved as his heart. It may be recognized in the poet's lines and creations, and its scent touches our breath.

\section{CONCLUSION}

No action goes unmentioned in our world: just as a wicked person is punished, a decent person gets the rewards of his or her good acts. Feinberg's contributions to Russian and Uzbek literature, in particular, did not go unnoticed. During the writer's lifetime, his efforts bore fruit. Despite the fact that the writer died 12 years ago, his work continues to bear fruit.

Alexander Feinberg was awarded the title of Honored Worker of Culture by the Republic of Uzbekistan on August 25, 1999, in acknowledgment of many years of productive work, a considerable contribution to the development of literature, and constructive participation in public affairs. On August 23, 2004, Alexander was awarded the People's Poet of the Republic of Uzbekistan. It is no secret that this title strengthens the Motherland's independence, raises our country's international prestige, contributes significantly to our people's culture and spirituality, earns national respect, demonstrates exceptional talent, multifaceted creativity, scientific activity, and science, many years of effective work in education, literature, culture, arts, health, sports, and other social spheres, and is a high title. Of course, the poet was well-deserving of the honor.

Alexander Arkadevich Feinberg, the People's Poet of Uzbekistan, was given the Pushkin Medal in 2008 by Presidential Decree. Alexander Feinberg, an Uzbek cinematographer and member of the Writers' Union of Uzbekistan, made a significant contribution to the establishment of cultural links between Russia and Uzbekistan. On April 2, 2009, he received the Pushkin Medal for his contributions to literature at the Uzbek State Academic Russian Drama Theater (by President of the Russian Federation Dmitry Medvedev's decree). We should not confuse this medal with the "A. S. Pushkin Medal," which was created in 1977 by the USSR Ministry of Education. This medal was the highest honorary award in the field of Russian language research areas. The award is presented each year to no more than ten people who have made substantial contributions to the study and development of the Russian language and culture, including Russian literature, art, and other subjects. The medal is awarded by the International Association of Teachers of Russian Language and Literature's national organizations.

I have enough hope. And the grave isn't the end of the path, as Alexander Feinberg points out. His statement was reasonably reliable. The poet's life did not stop after his death. For example, a statue of the People's Poet of Uzbekistan, Alexander Feinberg, was erected by sculptor M. Borodina in the Botkinsky Cemetery No. 1 in Tashkent.

On November 2, 2019, the People's Poet of Uzbekistan, Alexander Feinberg, would have turned eighty years old. On the same day, the Alisher Navoi National Library of Uzbekistan sponsored an event dedicated to the memory of Uzbek People's Poet Alexander Feinberg. A memorial plaque was erected in the house where the poet lived (Tashkent, Great Silk Road, 8). Relatives and friends of the poet, as well as students, gathered for the ceremony. The students of the 50th school, where A. Feinberg studied, amazed the audience so much that many even shed tears when they read the poem. People stood up and applauded. The wife of Feinberg, Inna Koval, was a small lady with a slight bend in her body, but the strength of her voice and the clarity of her ideas astounded everyone. He was handed an apple basket, but he insisted on everyone tasting it: "Please, help yourself." Koval, like her husband, was compassionate, forceful, generous, and open-handed.

A solemn ceremony was conducted at the Academic Russian Drama Theater on the same day. The audience was shown a movie by Jasur Is'hakov in which the poet was seen and heard. The producer gave a brief overview of the documentary's production, which was taken in one breath. The poet's acquaintances spoke out. The poetry of Alexander Feinberg was translated into Russian and Uzbek, and songs based on them were sung. 


\section{The Contribution of Alexander Arkadievich Feinberg's Work to Literature}

Elena Vetvikova has released a photo of a special event dedicated to the 80th anniversary of the People's Poet of Uzbekistan, Alexander Feinberg, at the Academic Russian Drama Theater of Uzbekistan.

A new project has been developed to create a unified literary and architectural ensemble in the Alley of Writers in 2020. At the moment, it is planned to erect a statue of 23 writers in the park. These are: Alisher Navoi, Zahiriddin Muhammad Babur, Ogahi, Muqimi, Furqat, Abdulla Avloni, Mahmudhoja Behbudi, Abdulla Qodiri, Cholpon, Oybek, Hamid Olimjon and Zulfiya, Abdulla Qahhor, Said Ahmad and Saida Zunnunova, Gafur G'ulom, Ozod Sharafiddinov, Erkin Vahidov, Abdulla Oripov, Ibrahim Yusupov, Tolepbergen Kayipbergenov, Alexander Feinberg and Muhammad Yusuf are a whole ensemble. All in all, it is obvious that the presence of a statue of Alexander Arkadievich Feinberg in the Alley of Writers is one of the boundless respects of the Uzbek people for the writer and his work.

\section{REFERENCES}

1) Alexander Fainberg "An Attempt to Autobiography"

2) Mikhail Knizhnik "Living Poet" Published in The Jerusalem Journal. Number 31, 2009

3) Elena Atlanova:Alexander " Feinberg's Cage of Freedom"

4) Alexander Fitz "About the poet Feinberg" Published in Khreshchatyk magazine number 4, 2005

5) "Literature and Art of Uzbekistan" newspaper, Number 24, 2009

6) Musurmonov R. "The Alley of Writers - the Garden of Enlightenment". -T .: Uzbek literature and art, June 19, 2020.

7) Alexander Feinberg. Chigir. T .: Sharq, 2007.

8) Islam Karimov. High spirituality is an invincible force. - T .: «Manaviyat», 2008. 136p.

9) Shuhrat Sirojiddinov Program and methodical manual for studying the life and work of Alexander Arkadievich Feinberg 